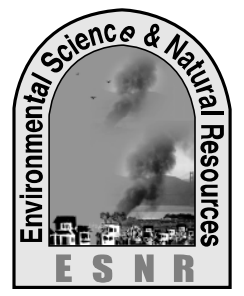

\title{
Effect of Different Substrate on Growth and Yield of Button Mushroom
}

\author{
M. J. Uddin, S. Haque ${ }^{1}$, M. E. Haque, S. Bilkis ${ }^{2}$ and A. K. Biswas ${ }^{3}$ \\ UAO, Department of Agricultural Extension, ${ }^{1}$ Department of Biotechnology, BAU, \\ Mymensingh, \\ ${ }^{2} \mathrm{SO}$, Sylhet Agricultural University, Sylhet and ${ }^{3} \mathrm{AE}$, Department of Agricultural Extension
}

\begin{abstract}
An experiment was conducted at the Mushroom growth house and Tissue Culture Laboratory, Horticulture Demonstration and Training Centre (HDTC), Kewatkhali, Mymensingh during February to May, 2006 to investigate the effect of different substrate on growth and yield of Button mushroom (Agaricus biporus). The substrates which were used in the experiment were wheat: paddy $(1: 1)$ straw compost, paddy straw compost and decomposed cowdung. The parameters observed in first and second flush were number of primordia, number of fruiting bodies and fresh weight of mushroom. Data were statistically analyzed following Completely Randomized Design (CRD). Data revealed that different substrate significantly affected the production of number of primordia, number of fruiting bodies and fresh weight. In both the first and second flush, all the three observed parameters were obtained highest in wheat: paddy straw compost and the lowest were in decomposed cowdung.
\end{abstract}

Keywords: Button mushroom, Fruiting bodies, Primordia, Substrate, Yield

\section{Introduction}

Among 20 very popular mushroom species, the white button mushrooms or crimini or portabella or portaballs mushrooms (Agaricus bisporus) have a higher commercial value (Jiskani et al., 1999). It is the interesting name for the mushroom where agaricus cleverly means gilled mushroom, has got pleasing, distinct taste and aroma. The epithet "biporus" refers to the two-shaped basidia lining the gills. This ensures that every spore that lands on a suitable substrate is capable of forming mushrooms.

A substrate is an important substance for growing mushrooms. Usually, a wide range of diverse cellulosic substrates are used for cultivating mushrooms. According to Jiskani et al. (1999) different agricultural and or industrial straw wastes can be used for cultivation of mushrooms Various agricultural byproducts are being used as substrates for the cultivation of oyster mushrooms, including banana leaves, peanut hull, corn leaves, mango fruits and seeds, sugarcane leaves, and wheat and rice straw (Cangy and Peerally,1995). In Asia, rice straw is widely used as the substrate for cultivating Oyster mushroom (Thomas et. al., 1998) and is also considered the best substrate for yield and high protein content. Wheat straw is commonly used as a substrate in Europe and sawdust is commonly used as a substrate in Southeast Asian countries for the cultivation of Oyster mushrooms. Hitherto, the button mushroom was the only mushroom cultivated on a large scale, using composted wheat straw as the substrate. The production and marketing potential of the milky white mushroom in Bangladesh is promising. Because of the high local demand for and export potential of this mushroom, many private entrepreneurs are interested in its commercial cultivation. This mushroom requires a temperature of $30-35^{\circ} \mathrm{C}$ and a relative humidity of $70-80 \%$ for cultivation, which are conducive to the environmental conditions of Bangladesh (Krishnamoorthy et. al., 2000). Huge quantities of lignocellulosic residues such as rice straw, wheat straw, mustard straw, maize straw, waste cotton, water hyacinth, sugarcane bagasse, coconut coir, and kash are generated annually through activities of the agricultural, forest, and food processing industries in Bangladesh. Being agriculture based country, Bangladesh has a large number of agricultural wastes which are available with a minimum cost and can be used as appropriate substrates for low cost mushroom cultivation. Therefore, the present investigation was undertaken to determine the best substrates for the cultivation of Agaricus bisporus.

\section{Methodology}

The experiment was conducted at the Mushroom growth house and Tissue Culture Laboratory, Horticulture Demonstration and Training Centre (HDTC), Kewatkhali, Mymensingh during February to May, 2006 to investigate the effect of different substrate on growth and yield of Button mushroom (Agaricus biporus). The substrates which were used in the experiment were: wheat and paddy (1:1) straw compost, paddy straw compost and decomposed cowdung. In preparing paddy straw compost, paddy straw $150 \mathrm{~kg}$, urea $4.5 \mathrm{~kg}$, TSP $3 \mathrm{~kg}$, MP $1.5 \mathrm{~kg}$, gypsum $7.5 \mathrm{~kg}, \mathrm{CaSO}_{4} 5 \mathrm{~kg}$, wheat bran $15 \mathrm{~kg}$, 
furadan $125 \mathrm{~kg}$ and bavistin $75 \mathrm{~kg}$ was used. About $20 \%$ paddy straw were spread on clean floor (2.5C) 2.5 (C)) and watering was done for soaking the straw. When the spread straw became 1 height, $1 / 5^{\text {th }}$ of ingredient was spreaded on the soaked straw. In this way $2^{\text {nd }}, 3^{\text {rd }}$ and $4^{\text {th }}$ layer was prepared. In the $5^{\text {th }}$ layer $50 \%$ straws was stacked and the rest $50 \%$ was spreaded on the ingredient as covering. After completing the compost heap swallow watering done for well decomposition and then covered with polythene sheet. At 4 days interval all the ingredients of compost heap became dried. After 40 days when it attained dark brown colour, it was used as substrate. In the wheat: paddy straw compost, $150 \mathrm{~kg}$ wheat straw, $150 \mathrm{~kg}$ paddy straw, urea $1.5 \mathrm{~kg}$, TSP $1.5 \mathrm{~kg}$, MP $1.5 \mathrm{~kg}$, wheat bran $7.5 \mathrm{~kg}$, molasses $2.5 \mathrm{~kg}$ and gupsum $15 \mathrm{~kg}$ was used. The wheat and paddy straw should be cut in to $5-8 \mathrm{~cm}$ long pieces and mixed thoroughly. Then the next procedure was followed as the same preparation of paddy straw compost. Five polypropylene bags for each substrate were prepared for continuing the experiment. The bottles containing different combinations and concentrations of growth regulators were sterilized for 2 hour at $121^{\circ} \mathrm{C}$ and $1.16 \mathrm{~kg} / \mathrm{cm}^{2}$ pressure in an autoclave and were kept 24 hours for cooling and then kept in a slant position for keeping the organism in pure culture. Then a piece of agar media $(1-2 \mathrm{~cm})$ containing mycelia as placed aseptically through the mouth of the bottles. The bottles plugged with cotton, were kept on wooden rake in laboratory room at $20-22^{\circ} \mathrm{C}$ for spawn run. After 10 day on wooden rake in laboratory room at $20-22^{\circ} \mathrm{C}$, the whole substrate became white due to fungal mycelia and then it (mother culture) was ready for spawning in different substrates. A small bit $(1 \mathrm{~cm})$ of mother culture was lifted on flame into the substrate packets. It was done in the Laminar Airflow Cabinet. Then the packets were placed side by side on the shelves in the shade house at $20-22^{\circ} \mathrm{C}$ for 21 days. All instruments, glassware and culture media were sterilized by autoclaved with 15 PSI at $121^{\circ} \mathrm{C}$ for $1-2$ hours. The culture room of the laboratory was cleaned by gently washing with detergent followed by $70 \%$ ethyl alcohol regularly. Matured mushrooms identified by curl margin of the cap were harvested by twisting to uproot from the base. Mushroom matured generally 48 hours after the appearance of primordia. After completing the first harvest the compost was covered with news paper and spraying water. Water was sprinkled on the naked substrates which were compact with mycelia twice a day. The primordial appeared 12-18 days after first harvest and then news paper was removed. Water spraying was continued until the mushrooms were ready to be harvested. The parameters that observed in first and second flush were number of primordia, number of fruiting bodies and fresh weight of mushroom. Recorded data were statistically analyzed following Completely Randomized Design (CRD). The analysis of variance was performed and means were compared by Least Significant Difference (LSD) test at 5\% level probability for interpretation of results (Gomez and Gomez, 1984).

\section{Results and Discussion}

\section{First flush}

\section{A. Number of primordia}

In the first flush, the number of primordial grown on different substrates differed significantly. The higher number of primordial (11.50) per bag was observed in wheat and paddy straw compost followed by paddy straw compost (9.50) and the lowest number of primordial was noticed in decomposed cowdung (96.33)(Table 1).The similar trend was also observed in second flush although the number of primordial was found lower compared to first flush.

Table 1. Effect of substrates on growth and yield of button mushroom in First flush

\begin{tabular}{|l|c|c|c|}
\hline \multicolumn{1}{|c|}{ Substrate } & $\begin{array}{c}\text { No. of } \\
\text { primodia/bag }\end{array}$ & $\begin{array}{c}\text { No. of fruiting } \\
\text { body/bag }\end{array}$ & $\begin{array}{c}\text { Yield of fruiting } \\
\text { body gm/bag }\end{array}$ \\
\hline Wheat: paddy straw (1:1) compost & $11.50 \mathrm{a}$ & $8.52 \mathrm{a}$ & $190.00 \mathrm{a}$ \\
\hline Paddy straw compost & $9.50 \mathrm{~b}$ & $7.00 \mathrm{~b}$ & $165.00 \mathrm{~b}$ \\
\hline Decomposed cowdung & $6.33 \mathrm{c}$ & $4.5 \mathrm{c}$ & $98.33 \mathrm{c}$ \\
\hline
\end{tabular}

The common letter(s) in a column did not differ at the level of 5\% probability as per DMRT

\section{B. Number of fruiting bodies}

The number of fruiting bodies in different substrates was statistically different, indicating that there was significant variation among the substrate for growing fruiting bodies (Fig. 1 and 2). The highest number of fruiting bodies (8.52 bag) was found from wheat: paddy straw compost and the lowest (4.5 bag) was produced in decomposed cowdung (Table 1).

\section{Yield}


Highest yield $(190.00 \mathrm{gm} / \mathrm{bag})$ was obtained from wheat and paddy straw compost followed by paddy straw compost $(165.00 \mathrm{gm} / \mathrm{bag})$ and the lowest yield

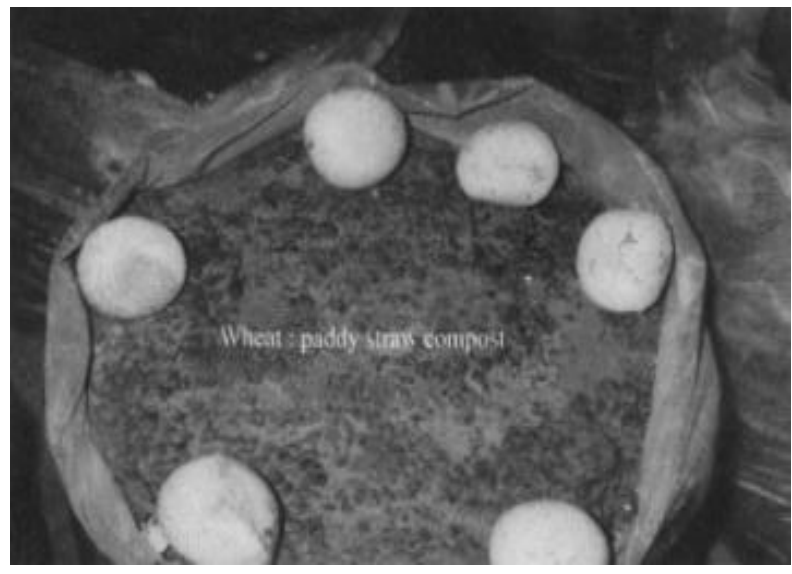

Fig. 1

Best fruiting body developed on wheat : paddy straw compost in first flush

\section{Second flush}

\section{A. Number of primordia}

Among the three different substrates wheat and paddy straw showed the best performance $(8.83 \mathrm{bag}$ ) for the
(98.33 gm/bag) was found in decomposed cowdung (Table 1). The mean value of yield of these three substrates was statistically significant.

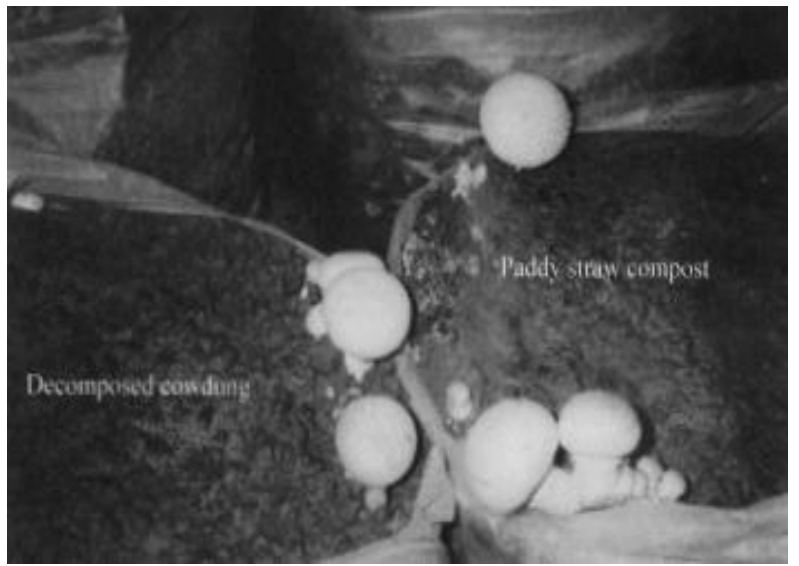

Fig. 2 Fruiting body developed on paddy straw compost and decomposed cowdung in first flush

production of primordial. Paddy straw compost gave less primordial 96.170 bag than that of wheat and paddy straw compost and more primordial than decomposed cowdung (4.17 bag) (Table 2$)$.

Table 2. Effect of substrates on growth and yield of button mushroom in Second flush

\begin{tabular}{|l|c|c|c|}
\hline \multicolumn{1}{|c|}{ Substrate } & $\begin{array}{c}\text { No. of } \\
\text { primodia/bag }\end{array}$ & $\begin{array}{c}\text { No. of fruiting } \\
\text { body/bag }\end{array}$ & $\begin{array}{c}\text { Yield of fruiting } \\
\text { body gm/bag }\end{array}$ \\
\hline Wheat and paddy straw (1:1) compost & $8.83 \mathrm{a}$ & $5.83 \mathrm{a}$ & $115.83 \mathrm{a}$ \\
\hline Paddy straw compost & $6.17 \mathrm{~b}$ & $4.50 \mathrm{~b}$ & $80.00 \mathrm{~b}$ \\
\hline Decomposed cowdung & $4.17 \mathrm{c}$ & $3.83 \mathrm{c}$ & $54.17 \mathrm{c}$ \\
\hline
\end{tabular}

The common letter(s) in a column did not differ at the level of 5\% probability as per DMRT

\section{B. Number of fruiting bodies}

The effect of fruiting bodies was also differed significantly in the second flush as found in the first flush (Fig. 3 and 4). The highest number of fruiting bodies $(5.83 \mathrm{bag})$ was found in wheat: paddy straw compost and the lowest $(3.83 \mathrm{bag})$ were in decomposed cowdung (Table 2).

\section{Yield}

The yield of mushroom was also significantly influenced in the second flush in these three different substrates. The highest yield was obtained from wheat: paddy straw compost (115.83 gm) followed by paddy straw compost $(80.00 \mathrm{gm} / \mathrm{bag})$ and the lowest yield $(54.16 \mathrm{gm} / \mathrm{bag})$ was found in decomposed cowdung (Table 2). The results indicated that there was significant variation among these three substrates. 


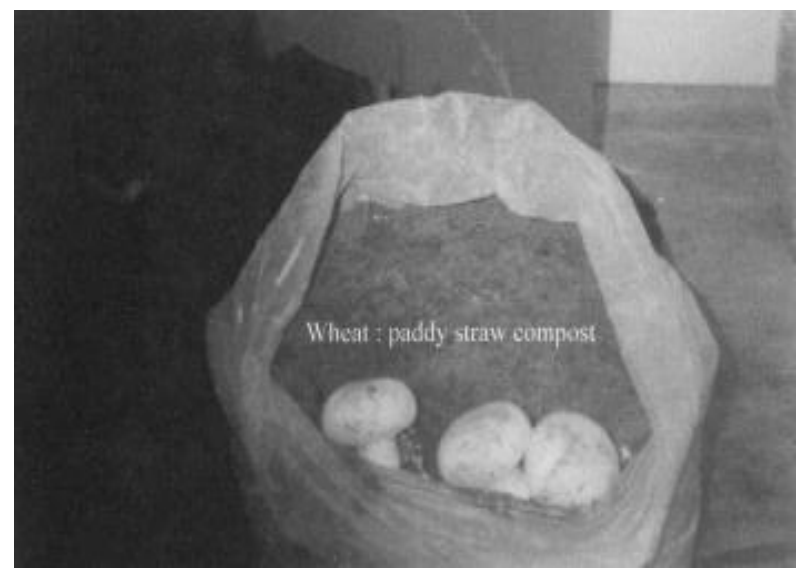

Fig. 3 Best fruiting body developed on wheat and paddy straw compost in second flush

\section{Conclusion}

From the above study it may be concluded that wheat and paddy straw compost was the best followed by paddy straw compost and decomposed cowdung substrate for the growth of button mushrooms. The protocol developed from the results of the present study may be useful for large scale production of mushroom. However, further research's needed to extend and improves technology to cultivate mushroom more efficiently.

\section{References}

Cangy, C. and Peerally. 1995. A Studies of Pleurotus production on sugarcane bagasse. African $J$. Mycol. Biotechnol., 3:67-79.

Gomez, K. A. and Gomez, A. A. 1984. Statistical procedure for Agricultural Research $\left(2^{\text {nd }}\right.$

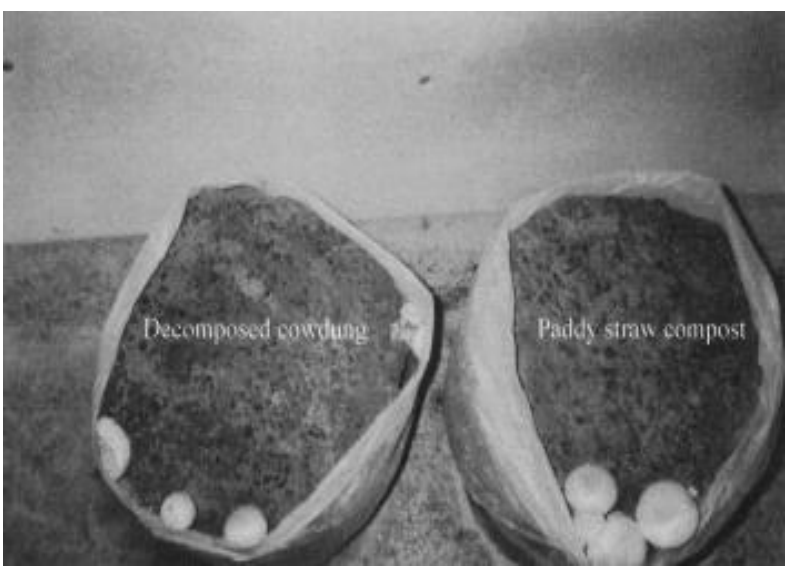

Fig. 4 Fruiting body developed on paddy straw compost and decomposed cowdung in second flush

edn). John Willy and Sons. New York. p.680.

Jiskani, M. M.; Pathan, M. A. and Wagan, K. H. 1999. Yield performance of Oyster mushroom Pleurotus florida (strain.,-PK401) on different substrates. Pakistan $J$. Agri., Agril. Engg., Vet. Sc. 15(2):26-29.

Krishnamoorthy, A. S.; Muthuswamy, M. T.; Nakkeeran, S. 2000. Technique for commercial production of milky mushroom Calocybe indica P\&C. Indian J. Mush. 18:19-23.

Thomas, G. V.; Prabhu, S. R.; Reeny, M. Z.; Bopaiah, B. M. 1998. Evaluation of lignocellulosic biomass from coconut palm as substrate for cultivation of Pleurotus sajor-caju (Fr.) Singer. World J. Microbiol. Biotechnol., 14:879-82. 